\title{
HARMS OF SECONDARY RECOGNITION IN THE CONTEXT OF SOCIOPOLITICAL CONFLICTS: THREE FACTORS FOR THEIR EXCLUSION FROM TRANSITIONAL JUSTICE LEGAL DISCOURSE
}

Ana Milena Coral Díaz

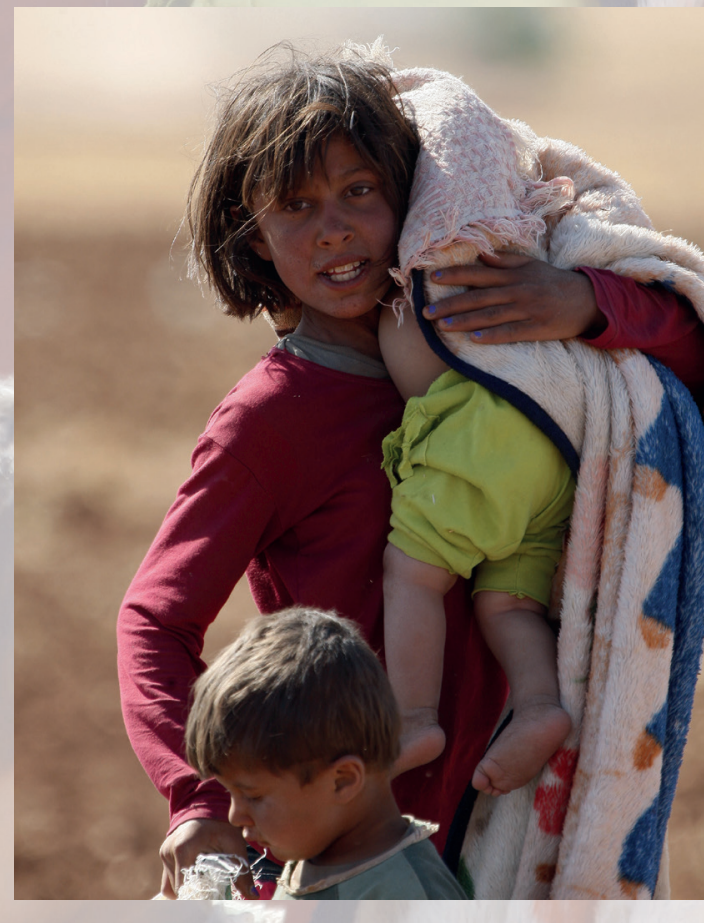

Código: 397441186 • Autor: kafeinkolik 



\title{
HARMS OF SECONDARY RECOGNITION IN THE CONTEXT OF SOCIOPOLITICAL CONFLICTS: THREE FACTORS FOR THEIR EXCLUSION FROM TRANSITIONAL JUSTICE LEGAL DISCOURSE
}

\author{
Ana Milena Coral Díaz \\ Universidad Católica de Colombia
}

\begin{abstract}
This work seeks to explain why feminist theory has said transitional justice legal discourse has not recognized the totality of harms women experience in the context of socio-political conflicts. To do so, it analyzes three factors responsible for international law and the Western construction of the female body as dualist and essentialist. Based on this analysis, it establishes that harms not usually recognized by this legal discourse are considered "harms of secondary recognition," since they do not form part of the typical legal figures that precede the experience itself.
\end{abstract}

Key Words: transitional justice, international law, feminism, secondary recognition harms, primary recognition harms

About the author: Doctor in Law from Colegio Mayor de Nuestra Señora del Rosario. Lawyer from Universidad Externado de Colombia. Specialist in human rights and international humanitarian law. Master in Anthropology from Universidad de los Andes. Researcher with the Center for Socio-legal Studies, Catholic University of Colombia Law School (CISJUC).

Received: March 3, 2020; evaluated: March 26, 2020; accepted: April 7, 2020. 


\title{
LOS DAÑOS DE RECONOCIMIENTO SECUNDARIO EN EL CONTEXTO DE CONFLICTOS SOCIOPOLÍTICOS: TRES FACTORES PARA SU EXCLUSIÓN DEL DISCURSO JURÍDICO DE JUSTICIA TRANSICIONAL
}

\author{
Ana Milena Coral Díaz \\ Universidad Católica de Colombia
}

\section{Resumen}

Este trabajo busca explicar la razón por la cual desde la academia feminista se ha dicho que el discurso jurídico de justicia transicional no ha reconocido la totalidad de los daños experimentados por las mujeres en el contexto de los conflictos sociopolíticos. Para ello, se analizarán tres factores responsables desde el derecho internacional y la construcción occidental del cuerpo femenino como uno dualista y esencialista. A partir de esta argumentación se establecerá que los daños no reconocidos usualmente por ese decurso jurídico son "daños de reconocimiento secundario", pues no forman parte de las figuras jurídicas típicas y los discursos que anteceden a la experiencia misma.

Palabras clave: justicia transicional, derecho internacional, feminismo, daños de reconocimiento primario, daños de reconocimiento secundario.

Autor: Doctora en Derecho del Colegio Mayor de Nuestra Señora del Rosario. Abogada de la Universidad Externado de Colombia. Especialista en Derechos Humanos y Derecho Internacional Humanitario Magíster en Antropología de la Universidad de los Andes. Investigadora del Centro de Investigación Jurídica de la Universidad Católica de Colombia (CISJUC).

Recibido: 3 de marzo de 2020; evaluado: 26 de marzo de 2020; aceptado: 7 de abril de 2020. 


\title{
OS DANOS PELO RECONHECIMENTO SECUNDÁRIO NO CONTEXTO DE CONFLITOS SOCIOPOLÍTICOS: TRÊS FATORES PARA SUA EXCLUSÃO DO DISCURSO JURÍDICO DA JUSTIÇA DE TRANSIÇÃO
}

\author{
Ana Milena Coral Díaz \\ Universidad Católica de Colombia
}

\section{Resumo}

Este trabalho pretende explicar a razão pela qual, a partir da academia feminista, se afirma que o discurso jurídico da justiça de transição não reconhece a totalidade dos danos experimentados pelas mulheres no contexto dos conflitos sociopolíticos. Para isso, são analisados três fatores responsáveis com base no direito internacional e na construção ocidental do corpo feminino como dualista e essencialista. Argumenta-se que os danos não reconhecidos usualmente por esse discurso jurídico são "danos pelo reconhecimento secundário", pois não fazem parte das figuras jurídicas típicas e dos discursos que antecedem a experiência em si.

Palavras-chave: justiça de transição, direito internacional, feminismo, danos pelo reconhecimento primário, danos pelo reconhecimento secundário.

Os autores: Doutora em Direito pelo Colegio Mayor de Nuestra Señora del Rosario. Advogada pela Universidad Externado de Colombia. Especialista em Direitos Humanos e Direito Internacional Humanitário. Mestra em Antropologia pela Universidad de los Andes. Pesquisadora do Centro de Pesquisa Jurídica da Universidad Católica de Colombia.

Recebido: 3 de março de 2020; avaliado: 26 de março de 2020; aceito: 7 de abril de 2020. 


\section{Introduction}

The feminist theory that has addressed the line of research related to transitional justice and international law has undertaken important work in relation to two aspects. The first is related to the quest to protect women's human rights in the face of serious violations of human rights and international humanitarian law (Gardam and Charlesworth 2000). The second has sought to redefine the lack of understanding that exists regarding the violation of women's human rights in the international context. ${ }^{1}$

This paper focuses on the second objective of feminist theory, as its academics work to demonstrate the failure of international law and transitional justice to recognize the harm caused to women in the context of socio-political conflicts. ${ }^{2}$ On the basis of this work, I argue the failure to include women's harms from "the full picture" is due to three main factors. The first is the sexualization of women in legal discourse; the second, the separation of public and private spheres in international law; and third, the limited knowledge of women's experience in armed conflicts and the resulting narrow definition of harms in legal discourse and international jurisprudence.

Understanding these factors allows us to comprehend why international criminal legal discourse generally, and transitional justice particularly, seems to replicate a universalistic discourse regarding harms women suffer related to wounds, which I refer to as "typical legal figures." The analysis carried out based on the three aforementioned factors also allows to critique this dualistic and fixed perspective regarding the understanding of sexual violence, the damages it causes and other violences women suffer during socio-political conflicts.

1 Nicola Henry, "Theorizing Wartime Rape: Deconstructing Gender, Sexuality, and Violence," Gender and Society 30, no. 1 (2016): 44-56. www.jstor.org/stable/24756163 (accessed February 3, 2020).

2 Hilary Charlesworth and Christine Chinkin, "An Alien's Review of Women and Armed Conflict," in Imagining Law: Essays in Conversation with Judith Gardam, eds. Stephens Dale and Babie Paul, 171-94. (South Australia: University of Adelaide Press, 2016), www.jstor.org/stable/10.20851/j.ctt1sq5x0z.12.2016 (accessed February 2, 2019).

3 Karima Bennoune, "Do We Need New International Law to Protect Women in Armed Conflict?" 38 Case Western Reserve Journal of International Law, 38 (2007): 363. 


\section{The importance of seeing the full picture: recognizing "harms of secondary recognition"}

The legal discourse that emerges from the universe of norms, jurisprudence, treaties, procedures, statutes, and others creates an official or institutional narrative of the violences and harms experienced during the conflict. ${ }^{4}$ Through legal sources, evidence, and arguments, legal discourse reconstructs the lived experience; thus legal discourse has the immense power to rebuild, but above all, to recognize.

From the dualistic perspective of the Western construction, in which the female body is shaped by biological essentialism, tied to sex and reproduction ${ }^{5}$ it can be affirmed that legal discourse has moved away from the experience, to focus on "harms of primary recognition." Harms of primary recognition are those that normally fit into the elaborate figures of international law to recognize, attribute criminal responsibility or define violence against women, and are generally based on an essentialist dualistic construction of women. By contrast, harms of secondary recognition ${ }^{7}$ are all the harms the specific victim has experienced.

Thus, harms of secondary recognition ${ }^{8}$ are generally not found in legal discourses, as procedural limitations prevent courts from hearing the narratives of women victims. In addition to this, they usually concentrate on typical figures that elaborate a reality based on stereotypes that improperly represent the context of harms. Thus, in international law harms of primary recognition are recognized while those of secondary recognition are not, and legal figures take precedence over the lived experience of the victim. By failing to recognize the entire universe of harms women suffer during armed conflicts, legal discourse creates a limited narrative of the experience. Moreover, the narratives and harms recognized as truth are often based on stereotypes.

The commitment to the knowledge of what actually happened is a potential act of social metamorphosis, as it creates and brings to light cracks in prevailing legal discourse and provides insight into what social and political strategies must be

Michelle Foucault, El orden del discurso, (Buenos Aires: Tusquets Editores, 1992).

Michelle Foucault, La voluntad del saber, (Madrid: Siglo XXI, 2009).

Ana Milena Coral-Diaz, Cuerpo Femenino en Transición, Estudio de Casos, (Bogotá: Universidad del Rosario, 2016).

Coral-Diaz, Cuerpo Femenino en Transición.

Coral-Diaz, Cuerpo Femenino en Transición. 
transformed to create a new scenario in which social coexistence and peace or democracy is possible. This commitment has become one of the most transformative elements of transitional justice theory and practice through the figure of "guarantees of non-repetition."

Harms -all of them- that are part of the full spectrum of truth, result from the perspective of social catharsis, a powerful element to question social backgrounds, practices, models, and endless political and social instruments that do not serve within the new model which claims to be established and for which it is necessary to rebuild the past.

Several academic works seek to explain the reasons for the failure to recognize the entirety of the harms women experience during socio-political conflicts. For

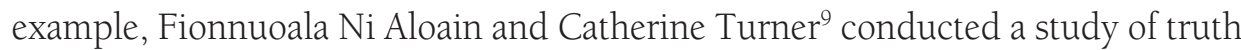
commissions created during the transition periods of Argentina and Chile. The authors concluded that the truth commissions could not recognize many harms experienced by women during the dictatorship because the substantive and procedural law did not permit the truth commissions to established harms according to the narrative experience of women victims. This failing limited knowledge of and the transformative potential of these experiences.

Similarly, Fionnuala Ni Aolain ${ }^{10}$ conducted a study about the Nazi holocaust and affirmed that the Nuremberg trials ignored most of the harms women experienced or absorbed them into other legal figures. Ni Aolain attributes this to the lack of knowledge of the female experience during the Holocaust from a gender perspective. Thus, for example, the separation of the family nucleus in concentration camps ${ }^{11}$ was totally invisible in the Nuremberg Trials, as was forced nudity, and the act of shaving women's heads. The author concludes that during the Nuremberg trials, international law adopted a narrow definition of the harms that women can potentially suffer during a war, which resulted in the absence of justice for the violence women suffered in concentration camps. This seems to indicate that the first stage of transitional justice ${ }^{12}$ already contained the foundations on which

9 Fionnuoala Ni Aolain and Catherine Turner, "Gender, Truth and Transition," UCLA Women's Law Journal, 16 (2009): 229-279.

10 Fionnuoala Ni Aolain, "Rethinking the Concept of Harm and Legal Categorizations of Sexual Violence During War," Theoretical Inquiries in Law, 1 (2009): 305.

11 Which constitutes, according to the author, a direct attack on the female body and female sexuality.

12 Ruty Teitel, Transitional Justice (New York: Oxford University Press, 2000). 
the concepts and elements to justify the limited recognition of harms women suffer during armed conflicts would be developed.

From this premise, and from the relevant literature, the following section of this article argues that legal discourse has privileged harms of primary recognition due to three main factors: (1) the sexualization of women in legal discourse; (2) the separation of public and private spaces in international law; and (3) the limited knowledge of women's experience in armed conflicts and the consequent narrow definition of harms in legal discourse and international jurisprudence. The first is elaborated as a general critique of law, while the others include a more detailed and specific critique of international law.

\subsection{The sexualization of the female body through legal discourse}

The feminist perspective presented here in relation to the sexualization of the woman's body through legal discourse, generally criticizes the law. It points out that only through the deconstruction of legal discourses, it is possible to unmask the apparent neutrality that distorts and marginalizes the experience of women by sexualizing the female body. Feminists such as Catherine MacKinnon, ${ }^{13}$ Carol Smart, ${ }^{14}$ Mary J. Frug, ${ }^{15}$ Michelle Stanworth ${ }^{16}$ and Robin West, ${ }^{17}$ among others, highlight the role of feminism to unearth and make visible what actually happens with women when they are victims of violence in patriarchal societies. Likewise, they discuss the law's understanding of sexual violence and its reinforcement of the reproductive role of women. The premise is to collectively raise awareness and show legal distortions and the law's limited understanding of women's experiences.

By sexualizing the female body, the law adopts the "body" aspect of the body/mind dualism feminists have widely questioned, as it projects an essentialist image of women, conditioned by the patriarchal gaze and devoid of the lived female experience and women's perspectives and represents the female body from the contingencies of sexuality and pregnancy.

13 Catherine MacKinnon, "Feminism, Marxism, Method, and the State: Toward a Feminist Jurisprudence," Signs, 8.4 (1983): 635-658;

Catherine MacKinnon, "Feminism Unmodified: Discourses on Life and Law" (London: Harvard University Press, 1987).

14 Carol Smart, Feminism and the Power of Law (London: Routledge, 1989).

15 Mary Joe Frug, Women and the Law (Westbury, NY: Foundation Press, 1992).

16 Michelle Stanworth, Reproductive Technologies: Gender, Motherhood and Medicine (Cambridge: Polit, 1987).

17 Robin West, "The Difference in Women's Hedonic Lives: A Phenomenological Critique of Feminist Legal Theory," Georgetown Public Law and Legal Theory Research Paper, 11.53 (2000): 149-215. 
For Catherine MacKinnon, the law is neutral, however, in reality, women's needs and experiences are denied. Abstract rights authorize male rights to the detriment of women. Thus, feminism questions whether legal discourse is actually neutral, and argues that to the he contrary, it marginalizes women's experience ${ }^{18}$.

This abstraction, which is embodied in the legal discourse, becomes even more evident in relation to certain specific figures that are openly debated in relation to, for example, abortion, a figure that is criminalized in many legal systems. Similarly, in relation to rape, as a figure within criminal law where harm is usually represented from penetration and from a heterosexual and masculine perspective. ${ }^{19}$

Law helps create the body's meaning. Mary Frug ${ }^{20}$ believes that the law allows and, in some cases, forces, the sexualization of the female body. This occurs when legal provisions criminalize individuals for sexual behavior, such as the rules against the sex trade or practices such as homosexuality. In parallel, rules are adopted that legitimize and support pornography and the eroticization of the female body through publicity and entertainment. Sexualization also occurs in the application of laws regarding rape and sexual harassment designed to protect women from sexual assault. According to Frug, ${ }^{21}$ these norms paradoxically guarantee or deny women protection based on their sexual history. The greater a woman's sexual availability, the less protection she obtains.

\subsection{The separation of public and private spheres in international law}

Public international law has not recognized the full experience of women. This is mainly due to the fact that women have been relegated to private sphere where

18 MacKinnon (1983) considers that only feminism incorporates the point of view of women and therefore, in its critical perspective, may warn that a right is not neutral; it may also show the "neutral" legitimacy upon which the right rests is questionable. By contrast, Carol Smart (1989) points out that both feminists and Marxists have criticized the notion of the essence of law derived from absolute truth. In different ways, both have argued that objective jurisprudence is a constructed appearance that reflects the power of law $(1989,68: 69)$. Smart believes the creation of feminist jurisprudence is not the ideal way to demonstrate law's male perspective and inequality because it reproduces the hierarchy of the law in and thus fetishizes it. Rather, the deconstruction of law itself can create important changes. In this regard, Smart argues: "It is not the space now occupied by traditional positivism or even abstract liberal jurisprudence that we seek to fill with another abstraction called" feminist jurisprudence- it seems to me - we seek to build feminine discourses with the right" (Smart, 1989, 69).

19 Catherine MacKinnon, Feminism Unmodified: Discourses on Life and Law.

20 Marie Joe Frug, "A Postmodern Legal Manifesto (An Unfinished Draft)," Harvard Law Review, 105 (1992): 1045-1075.

21 Frug, "A Postmodern Legal Manifesto (An Unfinished Draft). 
there is no recognition, which constitutes one of the main characteristics of public space. The private sphere instead, is the realm of what is not seen nor is the object of public appreciation. Therefore, many harms remain in the private sphere: harms experienced within the conflict as they are viewed as domestic violence, forced infatuation of civilian women with armed actors, so-called passion crimes that seem to have a personal motivation, or damages women endure within the subversive ranks, such as forced contraception or abortions. When considering these harms, the law often does not take into account the coercion and gender violence that underlie them.

Some feminists such as Catherine O'Rourke, ${ }^{22}$ Hilary Charlesworth, Cristine Chinkin and Shelley Wright, ${ }^{23}$ analyze international law from the dualistic logic of the public and private sphere and note a similar situation of invisibility and hierarchy in which, women, their needs and experiences are excluded from the public sphere. These author ${ }^{24}$ also show how women's voices are excluded from international law organizations, and how the normative structures of international law fails to recognize women's experiences.

\section{A. From the structural organization of international law}

States and increasingly international organizations are the primary subjects of international law. Women are absent from both subjects, their voices and perspectives invisible. State power structures are openly masculine, which is reflected in the high number of men in positions of power versus women. This means that women have not been represented in the global decision-making process. In addition, States' power is based on controlling the domestic monopoly of force that is also elitist and masculine. Armies and police forces are mostly composed of men, and their strategies and logic are masculine. International legal principles regarding sovereignty, political independence, territorial integrity, and the legitimate the use of force reinforce this aspect. ${ }^{25}$

In regards to women's representation in international law organizations and courts, data has established that women's participation considerably low compared to

\footnotetext{
Catherine O'Rourke, Gender Politics in Transitional Justice (London: Routledge, 2013).

23 Hilary Charlesworth, Christine Chinkin, and Shelley Wright, "Feminist Approaches to International Law," The American Journal of International Law, 85.4 (1991): 613-645.

24 Charlesworth, Chinkin, and Wright, "Feminist Approaches to International Law".

25 Charlesworth, Chinkin, and Wright, "Feminist Approaches to International Law".
} 
that of men, which creates an imbalance in the international legal sphere and also problems regarding access to justice. ${ }^{26}$ Above all, low representation of women limits the female perspective in the public sphere. For example, only six of the eighteen judges on the International Criminal Court are women, ${ }^{27}$ fourteen of the 46 judges on the European Court of Human Rights are women ${ }^{28}$ and three of fifteen judges of the International Court of Justice are women. ${ }^{29}$ With respect to international legal organizations, as of the $70^{\text {th }}$ anniversary of the International Commission of Justice (ICL), only seven of the organizations total 229 members have been women. ${ }^{30}$

\section{B. From the normative structure of international law}

The normative structures of international law and those that operationalize transitional justice mechanisms have accentuated women's exclusion from the public sphere. For example, the figure of torture as defined in article 1 of the Convention Against Torture provides a clear example of the separation between the public and private sphere in the description of the action as well as the harms that result from this action, in which female suffering is excluded.

\section{Article 1}

1. For the purposes of this Convention, the term "torture" means any act by which severe pain or suffering, whether physical or mental, is intentionally inflicted on a person for such purposes as obtaining from him or a third person information or a confession, punishing him for an act he or a third person has committed or is suspected of having committed, or intimidating or coercing him or a third person, or for any reason based on discrimination of any kind, when such pain or suffering is inflicted by or at the instigation of or with the consent or acquiescence of a public official or other person acting in an official capacity. It does not include pain or suffering arising only from, inherent in or incidental to lawful sanctions.

26 Priya Pillai, "Women in International Law: A Vanishing Act?" http://opiniojuris.org/2018/12/03/women-in-international-law-a-vanishing-act/ (accessed December 20, 2019).

27 International Criminal Court, "Current Judges" https://www.icc-cpi.int/about/judicial-divisions/biographies/Pages/current-judges.aspx (accessed December 20, 2019).

28 European Court of Human Rights, "Composition of the Court" https://www.echr.coe.int/Pages/home. aspx? $\mathrm{p}=$ court/judges\&c $=($ accessed December 20, 2019).

29 International Court of Justice, "Current members" https://www.icj-cij.org/en/current-members (accessed December 20, 2019).

30 Pillai, "Women in International Law: A Vanishing Act?" 
Hilary Charlesworth ${ }^{31}$ argues this definition does not allow us to understand the experience of suffering of many women. First, the definition states the purpose of torture is to punish, intimidate, coerce, obtain information or confession, but in armed conflicts, women are often victims of massive acts of violence for no clear purpose, at the hands of State security forces or illegal armed groups. Moreover, the definition assumes a State official acting in his official capacity carries out torture in the public sphere. By contrast, in many cases women suffer private acts of brutality, or the "official" status of the acts and the actor are unclear, and thus, this type of damage is considered excluded from the definition of torture. ${ }^{32}$

Similarly, Catherine O'Rourke conducted a comparative study of the transitions in Chile, Northern Ireland, and Colombia and found these States ignored or even condoned some private harms. ${ }^{33}$ Issues such as domestic violence, repressive regulation of women's lives, and manipulation of women's collective organizations, among others, are invisible in the private sphere, perpetuating impunity. ${ }^{34}$

\subsection{Limited knowledge of women's experience in socio-political conflicts and the narrow definition of harms in legal discourses}

Feminist academics critique the instruments of international humanitarian law (IHL) and international criminal law for ignoring the violence that women experience during socio-political conflicts. This lack of knowledge translates into the recurrent representation of women in an essentialist and dualistic way, in which gender stereotypes persist. The limited knowledge of the feminine experience reinforces a narrow definition of the harms women experience during conflicts, as viewing the world through a male lens creates a distorted situation in which where certain harms are recognized while others are ignored. The masculine perspective also defines and interprets violence, especially sexual violence. This results in discrimination, a lack of effective protection, and impunity, among other negative consequences. The following section provides examples of the absence of a female perspective in the legal provisions and jurisprudence from international courts regarding IHL.

\footnotetext{
Charlesworth, Chinkin, and Wright, "Feminist Approaches to International Law".

Charlesworth, Chinkin, and Wright, "Feminist Approaches to International Law".

O'Rourke, Gender Politics in Transitional Justice.

O'Rourke, Gender Politics in Transitional Justice.
} 
A. The shortcomings of international humanitarian law in recognizing women's experiences in armed conflicts

Julieth Gardam and Michelle Jarvis ${ }^{35}$ have argued socio-political conflicts exacerbate the pre-existing inequalities facing women, while IHL provisions do not reflect women's experiences during conflicts. ${ }^{36}$ War creates an open fire environment, a space with no order or limits, where stereotyped and misogynistic ideas about women have free reign. This often leads armed actors to commit to acts of violence and discrimination against women. The conflict exacerbates daily gender-based violence against women based on sexist ideas. ${ }^{37}$

Feminists argue IHL norms are ineffective at protecting women due to their very content, as they reproduce the gender stereotypes and perpetuate discrimination. Gardam and Jarvis have stated: "it is apparent from a comparison between the reality of armed conflict for women [...] and the existing relevant norms of international law, that the latter are inadequate." 38

Specifically, Judith Gardam and Michelle Jarvis ${ }^{39}$ consider the Geneva Conventions and their additional 1977 protocols prioritize the needs of male combatants, while women are relegated to the condition of victims - generally of sexual violence - or are legitimate only when performing reproductive or childrearing functions. ${ }^{40}$ The authors state of the 42 provisions related to women, almost half refer to women who are pregnant or breastfeeding. ${ }^{41}$ Likewise, the regulations to protect women from sexual violence are expressed in terms of chastity and modesty. Again the female body is sexualized body in these norms. ${ }^{42}$ Feminist human rights experts also have strongly criticized the list of serious violations included in the conventions and Protocol I for failing to expressly include reference to gender-based harms, which reflects the ignorance regarding the severity of such harms. ${ }^{43}$ Thud, feminists claim

\footnotetext{
35 Judith Gardam and Michelle Jarvis, Women, Armed Conflict and International Law (The Hague: Kluwer Law International, 2001).

36 Charlesworth and Chinkin, "An Alien's Review Of Women And Armed Conflict".

37 Bennoune, "Do We Need New International Law to Protect Women in Armed Conflict?"

38 Judith Gardam and Michelle Jarvis, "Women and Armed Conflict: The International Response to the Beijing Platform for Action," Columbia Human Rights Law Review, 1.56 (2000): 363, cited in Bennoune, "Do We Need New International Law to Protect Women in Armed Conflict?"

39 Gardam and Jarvis, "Women, Armed Conflict and International Law".

40 Helen Durham and Katie O’Byrne, "The Dialogue of Difference: Gender Perspectives on International Humanitarian Law," International Review of the Red Cross, 92 (2010): 31-52.

41 Gardam and Jarvis, "Women, Armed Conflict and International Law".

42 Gardam and Jarvis, "Women, Armed Conflict and International Law".

43 Gardam and Jarvis, "Women, Armed Conflict and International Law".
} 
IHL fails to contemplate women's full experience in armed conflicts, but rather is limited to a patriarchal and stereotyped vision of women

Karima Bennoune ${ }^{44}$ created a list of harms women suffer in armed conflicts, which includes not only those caused by sexual violence, but also harms related to the deprivation of social and cultural economic rights, the lingering effects during the post-conflict and those related to gender-based abuse. Although the list only seeks to expose some of these harms, offers a broader and more comprehensive view of women's experiences in conflicts. The gender-based abuse includes rape, which could be considered a harm of primary recognition, ${ }^{45}$ and the deprivation of social, economic, and cultural rights, such as the destruction, demolition, and expropriation of the home, denial of health care attention, and the lack of adequate sanitary conditions and public services, especially during menstruation and breastfeeding, education and employment opportunities, and adequate medical and rehabilitation care, including maternity and reproductive care. Other harms include discrimination against women who have given birth to children conceived through rape, shame imposed on the victim's family, and perhaps one of the most frequent in cultural contexts that understand harms from a patriarchal perspective: impunity for the perpetrators of gender-based harms. ${ }^{46}$

\section{$B$. The recognition of sexual violence by international courts}

Feminist lawyers began pushing international criminal tribunals to recognize women's experiences in armed conflicts during the 1990s, working to include sexual violence as international crimes in the statues that created the international tribunals for Rwanda and Yugoslavia and the International Criminal Court. ${ }^{47}$ Feminists' objective was to establish the ways in which women experience harms. The idea was to show the differential impact armed conflicts have on women. ${ }^{48}$

Feminists also sought to connect the harms of sexual and gender-based violence to the definition of genocide and other crimes within international criminal law. ${ }^{49}$ The

\footnotetext{
44 Bennoune, "Do We Need New International Law to Protect Women in Armed Conflict?"

45 As it belongs to the dualistic perspective of the Western construction of the female body.

46 Bennoune, "Do We Need New International Law to Protect Women in Armed Conflict?"

47 Doris Buss, "Performing Legal Order: Some Feminist Thoughts on International Criminal Law," International Criminal Law Review, 11 (2011): 409-23.

48 Buss, "Performing Legal Order".

49 Buss, "Performing Legal Order".
} 
Kunarac $^{50}$ and Akayesu ${ }^{51}$ decisions were important in meeting this objective, as they permitted establishing a causal link between sexual violence against women and the intention to destroy all or part of the communities affected by this strategy of war.

A third objective was to highlight how the violence women suffer during conflicts is made possible largely by the violence and inequality women face in peacetime. ${ }^{52}$ Feminists jurists sought to demonstrate that harms have a particular nature, a gender nature, in which this women are victims of a conflict that exacerbates conditions of inequality and discrimination. Thus, phenomena such as sexual violence could not be seen as isolated, but rather related to broader contexts of oppression that precede the conflict.

For Doris Buss, ${ }^{53}$ failing to understand the full meaning of violence against women during armed conflicts is contradictory to the purpose of international justice. This gap reproduces systems of inequality and discrimination, which in turn facilitates sexual violence. Transitional justice mechanism have thus focused on the victim's community or aggressor, setting aside the impacts on the actual victim and defining them according to social and cultural representation systems. Communities rebuilding after a conflict must modify these structures in order to eliminate inequality of women and thus prevent the occurrence of similar acts of violence. For Buss, although international criminal law has responded to some feminist criticism, it does not yet recognize fully the violences and harms women experience during conflicts.

\section{Conclusions}

The fundamental premise of this article is the following: Legal discourse has failed to recognize harms caused to women in armed conflicts from their experience. This premise is based on feminist critique of transitional justice and international law. The article provides an overview of the feminist critique of the law, in particular international law to consider three factors that explain why international law has failed to recognize harms from women's bodily experience, which constitute harms of secondary recognition. Legal discourse has moved away from experience to focus on

\footnotetext{
50 International Criminal Tribunal for the Former Yugoslavia, Prosecutor v. Kunarac et al., 2001, Case no. IT-9623-T \& IT-96-23/1-T.

51 International Criminal Tribunal for Rwanda, Prosecutor v. Akayesu, 1998, Case no. ICTR-96-4-T.

52 Nicola, "Theorizing Wartime Rape".

53 Buss, "Performing Legal Order".
} 
harms of primary recognition, which are based on the dualistic, essentialist perspective of the Western construction of the female body, linked to sex and reproduction.

Regarding the first factor, the sexualization of the female body through legal discourse, the article shows how although this sexualization is shown as impartial and objective, it is actually based on a male perspective that sexually objectifies women's bodies and uses a masculine paradigm to define violence. Under this paradigm, women are defined as sexual and reproductive beings, irrational and dominated by passions, according to the mind/body dualism feminism has questioned for representing women's experience in a purely bodily way. Law reinforces motherhood as natural and desired, and sexualizes the female body through its discourse on sexual violence, especially regarding the definition of rape.

Women are deprived of their own experience, since they must adapt to legal definitions that exclude female experiences, limited to the masculine world presented through seemingly neutral terms. The lived body that is interwoven with cultural and historical meanings, gender representations and women's experiences are ignored. For authors such as Catherine MacKinnon, Carol Smart, Mary J. Frug, Robin West, feminism is the path to the deconstruction of this objectified discourse and the way of talking about women's experience on their own terms. It is through awareness and deconstruction that male bias is made visible and changes to include the female experience in the law may be proposed.

The second factor is the separation of the public and private sphere in international law. Feminist critique argues the public sphere of international law fails to recognize the female experience in armed conflicts. The scarce participation of women in power structures, the normative structure and the marginalization of certain harms as private influence this situation. This is mainly due to the fact that women have been relegated to the private sphere, and thus, many harms remain in the private sphere. Harms women experience in the conflict may be viewed as domestic violence, while those women endure within the subversive ranks, such as forced contraception and abortions, the forced infatuation of civil women with armed actors or so-called passion crimes are considered to be personally motivated, rather than the result of the armed conflict. However, this perspective fails to take into account the situations of coercion and gender violence that underlie them. Prioritization policies in the investigation and prosecution of crimes committed during the armed conflict reinforce this situation, since the State ignores or condones many "private" 
damages in order to the focus investigations on what it considers more relevant or more serious crimes committed in armed conflicts.

The third factor is the limited knowledge of women's experience in socio-political conflicts and the consequent narrow definition of harms in legal discourse. Feminist voices focus on armed conflicts to question the precariousness with which international law understands and projects women's experience. For feminists, this narrowness results in the representation of women in a stereotyped and essentialist way in relation to sex, modesty, motherhood, and the masculine perspective that defines violence. In turn, this results in the limited definition of harms in legal instruments.

\section{References}

Coral-Díaz, Ana Milen. Cuerpo Femenino en Transición, Estudio de Casos. Bogotá: Universidad del Rosario, 2016.

Smart, Carol. Feminism and the Power of Law. London: Routledge, 1989.

MacKinnon, Catherine. "Feminism, Marxism, Method, and the State: Toward a Feminist Jurisprudence." Signs 8, no. 4 (1983): 635-658.

O'Rourke, Catherine. Gender Politics in Transitional Justice. London: Routledge, 2013.

Buss, Doris. "Performing Legal Order: Some Feminist Thoughts on International Criminal Law." International Criminal Law Review 11 (2011): 409-23.

European Court of Human Rights. "Composition of the Court." https://www.echr.coe.int/ Pages/home.aspx? $\mathrm{p}=\mathrm{court} / \mathrm{judges} \& \mathrm{c}=($ accessed December 20, 2019) .

Ni Aolain, Fionnuoala, "Rethinking the Concept of Harm and Legal Categorizations of Sexual Violence During War," Theoretical Inquiries in Law 1 (2009): 305.

Ni Aolain, Fionnuoala \& Catherine Turner. "Gender, Truth and Transition." UCLA Women's Law Journal 16 (2009): 229-279.

Nicola, Henry. "Theorizing Wartime Rape: Deconstructing Gender, Sexuality, and Violence." Gender and Society 30, no. 1 (2016): 44-56. www.jstor.org/stable/24756163 (accessed February 3, 2020).

Charlesworth, Hilary and Christine Chinkin, "An Alien's Review of Women and Armed Conflict." in Imagining Law: Essays in Conversation with Judith Gardam. eds. Dale Stephens \& Paul Babie Paul. 171-94. South Australia: University of Adelaide Press, 2016). www.jstor.org/stable/10.20851/j.ctt1sq5x0z.12.2016 (accessed February 2, 2019). Charlesworth, Hilary \& Christine Chinkin, "An Alien's Review of Women and Armed Conflict." Opinio Juris, (2028). http://opiniojuris.org/2018/12/03/women-in-international-law-a-vanishing-act/ (accessed December 20, 2019). 
International Criminal Tribunal for the Former Yugoslavia. (2001). Prosecutor v. Kunarac et al. Case no. IT-96-23-T \& IT-96-23/1-T.

International Criminal Tribunal for Rwanda. (1998). Prosecutor v. Akayesu. Case no. ICTR-96-4-T.

International Court of Justice. "Current members." https://www.icj-cij.org/en/current-members (accessed December 20, 2019).

International Criminal Court, "Current Judges," https://www.icc-cpi.int/about/judicial-divisions/biographies/Pages/current-judges.aspx (accessed December 20, 2019).

Gardam, Judith \& Michelle Jarvis. "Women and Armed Conflict: The International Response to the Beijing Platformfor Action." Columbia Human Rights Law Review, 32 (2000): 363.

Gardam, Judith \& Michelle Jarvis. Women, Armed Conflict and International Law. The Hague: Kluwer Law International, 2001.

Gardam, Judith \& Hilary Charlesworth. "Protection of Women in Armed Conflict." Human Rights Quarterly, 22 no. 1 (2000): 148-66. www.jstor.org/stable/4489270 (accessed February 3, 2020).

Bennoune, Karima. "Do We Need New International Law to Protect Women in Armed Conflict?" Case Western Reserve Journal of International Law, 38 (2007): 363. https:// scholarlycommons.law.case.edu/jil/vol38/iss2/6.

Frug, Marie Joe, "A Postmodern Legal Manifesto (An Unfinished Draft)." Harvard Law Review, 105 (1992): 1045-1075.

Frug, Mary Joe, Women and the Law. Westbury, N.Y: Foundation Press, 1992.

Foucault, Michele. El orden del discurso. Buenos Aires: Tusquets Editores, 1992.

Foucault, Michele. La voluntad del saber. Madrid: Siglo XXI, 2009.

Michelle Stanworth, Reproductive Technologies: Gender, Motherhood and Medicine. (Cambridge: Polit, 1987).

Pillai, Priya. "Women in International Law: A Vanishing Act?" Opinio Juris (2018). http:// opiniojuris.org/2018/12/03/women-in-international-law-a-vanishing-act/ (accessed December 20, 2019).

West, R. "The Difference in Women's Hedonic Lives: A Phenomenological Critique of Feminist Legal Theory." Georgetown Public Law and Legal Theory Research Paper, 11 no. 53 (2000): 149-215.

Teitel, Ruty. Transitional Justice. New York: Oxford University Press, 2000. 